\author{
Dr. sc. Sanja Grbić, docentica \\ Dr. sc. Dejan Bodul, docent \\ Pravni fakultet Sveučilišta u Rijeci
}

\title{
O USTAVNIM I KONVENCIJSKIM DVOJBAMA UZ ZAKON O STEČAJU POTROŠAČA - predstavlja li višegodišnji plan otplate duga u Zakonu o stečaju potrošača povredu prava na suđenje u razumnom roku? ${ }^{1}$
}

\author{
UDK: $35: 342(4)$ \\ Izvorni znanstveni rad \\ Primljeno: 1. 5. 2016.
}

\begin{abstract}
Precedentalni karakter prava Europske konvencije za zaštitu ljudskih prava i temeljnih sloboda (dalje: Europska konvencija ili EKLJP), koja se kroz praksu Europskog suda za ljudska prava (dalje: Europski sud ili ECHR) razvija kao „živi“ instrument, doveo je do toga da svaki od pojmova iz čl. 6 zahtijeva objašnjenje na stotine stranica. U navedenom kontekstu ECHR je u svojim presudama analizirao i tzv. ,prešutna prava“ koja nisu izričito navedena u tekstu Konvencije već su stvorena kroz judikaturu za, exempli causa, stečajni (korporativni i potrošački) postupak. S druge strane, činjenica je da stečaj predstavlja izvansudski postupak, in extremis, u kojem je vrijeme jedan od najznačajnijih elemenata. Vrijeme umanjuje vrijednost imovine i što više vremena protekne u stečajnom postupku, vjerovnicima će okončanjem postupka biti u pravilu dostupna manja količina novčanih sredstva, dok su paralelno i dužnici - potrošači zakinuti jer imaju manje šanse za ekonomsko-socijalnu „rehabilitaciju“. U ovom radu bavimo se analizom dviju komplementarnih tema koje smo tijekom argumentacije povezali u jedinstvenu cjelinu. Naime, u navedenom kontekstu autori preispituju hoće li višegodišnje trajanje postupka potrošačkog stečaja (u nekim slučajevima i do 7 godina) definirano Zakonom o stečaju potrošača predstavljati povredu prava na suđenje u razumnom roku odnosno povredu prava na rješavanje građanskih prava i obveza dužnika i vjerovnika u razumnom roku iz čl. 6. EKLJP-a i čl. 29. Ustava RH. Kompleksnost predmeta istraživanja i postavljeni zadaci uvjetovali su izbor metoda pa je u istraživanju korišten metodološki pristup koji obuhvaća proučavanje domaće i strane literature, odgovarajućih zakonskih propisa kao i analizu sudske prakse. U radu se posebno analizira praksa Europskog suda za ljudska prava u postupcima uz čl. 6. (Pravo na pošteno suđenje) i Ustavnog suda RH uz čl. 29., st. 1. Ustava RH jer polazimo od pretpostavke da saznanja o ovome mogu biti ključna za razumijevanje problematike rada.
\end{abstract}

Ključne riječi: Zakon o stečaju potrošača, razdoblje provjere ponašanja, standard razumnog roka

1 Ovaj rad nastao je uz potporu Hrvatske zaklade za znanost u okviru projekta 6558 Business and Personal Insolvency - the Ways to Overcome Excessive Indebtednes. 


\section{UMJESTO UVODA}

Pri transplantaciji novih pravnih rješenja u doktrinarnim raspravama redovito se pojavljuje pitanje treba li slijediti tradicionalne kontinentalno-europske modele, ili možda anglosaksonske modele. ${ }^{2}$ Hrvatski je zakonodavac, po uzoru na kontinentalnopravnu tradiciju, bitno reformirao stečajno pravo 1997. ${ }^{3}$ Jedna od značajnijih novina u odnosu na ranije uređenje stečajne materije, implementacija je i instituta stečaja nad imovinom dužnika pojedinca (obrtnika i trgovca pojedinca) (čl. 282.-300. starog SZ). ${ }^{4}$ Ipak, odredbe pozitivnog prava koje se odnose na stečajni postupak nad imovinom dužnika pojedinca jedne su od rijetkih koje nisu doživjele bitne izmjene od donošenja SZ-a, tj. od 1996., pa do zadnjih novela starog SZ-a i novog Stečajnog zakona. ${ }^{5}$ To možemo objasniti činjenicom da su stečajni postupci nad imovinom dužnika pojedinca bili rijetki te je većina odredbi u potpunosti ostala „neiskušana“ u praksi. ${ }^{6}$ Dakle, primjena SZ-a u odnosu na dužnike pojedince još nije utvrdila odgovarajuće standarde za pojedine probleme, pa će se tek u budućnosti trebati iskristalizirati određena tumačenja. ${ }^{7}$ Ipak, stečajni postupak nad imovinom dužnika pojedinca, kako je uređen u starom SZ-u, predstavljao je prvi korak prema otvaranju mogućnosti implementacije stečajnog postupka nad imovinom svih fizičkih osoba, odnosno uvođenju potrošačkog stečaja. ${ }^{8}$ Do 2014. zakonodavac je samo Polaznim osnovama za uvođenje Instituta osobnog bankrota kao i Nacrtom prijedloga iskaza o procjeni učinaka propisa za pripremu nacrta prijedloga Zakona o stečaju potrošača napravio skroman iskorak u odnosu na rješenja koja se tiču stečajnog postupka nad imovinom svih fizičkih osoba. ${ }^{9}$

2 Bodul, D. et al., „Pitanja pravnog transplantiranja stečajnog zakonodavstva - kolizija pravne tradicije i ekonomskih čimbenika“", Zbornik Pravnog fakulteta Sveučilišta u Rijeci, vol. 35, 2014 ., no. 2, str. 555-595. Isto vidi, Legrand, P., „The Impossibility of Legal Transplants“, Maastricht Journal of European and Comparative Law, vol. 4, 1997., str. 111. et seq.

3 NN, 44/96., 29/99., 129/00., 123/03., 82/06., 116/10. 25/12., 133/12. i 45/13. - stari SZ. Podrobnije Dika, M., Insolvencijsko pravo, Pravni fakultet, Zagreb, 1998., str. 1-154.

4 Vidi Čuveljak, J., ,Oslobođenje od preostalih obveza u stečajnom postupku“, Pravo u gospodarstvu, vol. 48., 2008., br. 3, Zagreb, str. 955-970.

5 NN, 71/15. od 01. rujna 2015. - dalje: SZ. Podrobnije Marković, N. i Kuzmić, M. (ur.), Reforma hrvatskog insolvencijskog prava - novi Stečajni zakon, Inženjerski biro, Zagreb, 2015., str. 1-267.

6 Lovrić, V., Stečaj nad imovinom dužnika pojedinca. Dostupno na mrežnim stranicama Visokog trgovačkog suda (17. siječnja 2016.).

7 Primjerice, Bodul, D., ,Odvjetnik kao pasivno legitimirana stranka u postupku stečaja potrošača rješenja i dvojbe“", Hrvatska pravna revija, 2016., br. 4, str. 48-58.

8 Vidi, Garašić, J., „Kako zakonski regulirati „osobni stečaj“ u Hrvatskoj“, Zbornik Pravnog Fakulteta Sveučilišta u Zagrebu, vol. 61, 2011., no. 5, str. 1487-1514.

9 Tekstovi radnih verzija dostupni su kod autora i na stranicama Ministarstva pravosuđa. Isto vidi, Bodul, D., „Osobni stečaj - globalni trend i hrvatska perspektiva“, Zbornik Pravnog Fakulteta Sveučilišta u Rijeci, vol. 32, 2011., br. 1, str. 351-377. 


\section{POČELA ZAKONA O STEČAJU POTROŠAČA (NN, 100/15 NA SNAZI OD 01. SIJEČNJA 2016.)}

Provedbu kao i cilj stečajnog postupka detaljno uređuje SZ. ${ }^{10} \mathrm{U}$ pravnom smislu, stečaj je izvanparnični sui generis sudski postupak u kojem se vrši kolektivno namirenje svih vjerovnika iz imovine insolventnog dužnika, bilo kroz likvidacijski stečajni postupak ili kroz neki model reorganizacije. Iako se u ovim pogledima vidi određena različitost, oba upućuju na dva osnovna cilja stečaja, a to je namirenje vjerovnika i ostvarivanje njihovih imovinskih zahtjeva, ali i gašenje poslovnog subjekta koji nije u mogućnosti izvršavati svoje obveze (čl. 2. SZ-a). Pravna teorija ukazujena to da se kod postupka stečaja potrošača razlikuje materijalno-pravni cilj, tzv. fresh start za dužnika potrošača - koji se odnosi samo na dužnika i predstavlja differentia specifica u odnosu na stečaj pravnih osoba. ${ }^{11}$ Ipak na postulatima financijskog oporavka koji je zagovaran kroz institut predstečajnih nagodbi, a sada kroz institut stečajnog plana i predstečajnog postupka, implementiran je i Zakon o stečaju potrošača. ${ }^{12}$ Naime, u reorganizaciji trgovačkog društva, kao vidu alternative likvidacijskom stečaju, primjećujemo određene sličnosti s institutom stečaja nad imovinom potrošača (čl. 4.) budući da je „ekonomsko ozdravljenje“ potrošača kao subjekta postupka upravo i primarni cilj (čl. 2. ZSP-a). Stoga, sukladno pravilima ZSP-a, ratio ovog izvanparničnog postupka sui generis jest poštenog potrošača osloboditi od obveza koje preostanu nakon unovčenja njegove imovine i raspodjele prikupljenih sredstava vjerovnicima (oslobođenje od preostalih obveza) (čl. 2., st. 1. ZSP-a). Pritom, posebne insolvencijske odredbe pružaju potrošačima pravo na otpust dugova u tri etape.

\subsection{Etape postupka stečaja potrošača}

Prva je etapa određena u pokušaju potrošača da postigne izvansudski sporazum o ispunjenju obveza sa svojim vjerovnicima. Pokušaj, a ne postizanje izvansudskog sporazuma o reguliranju duga, preduvjet je pokretanja sudskog stečajnog postupka (čl. 8.-20. ZSP-a).

10 Stupanjem na snagu SZ-a prestao je važiti stari SZ kao i većina odredbi o predstečajnoj nagodbi iz Zakona o financijskom poslovanju i predstečajnoj nagodbi (NN, 108/12., 144/12., 81/13. i 112/13. (71/15. i 78/15.) - dalje: ZFPPN) (čl. 445. SZ-a).

11 Podrobnije Radović, V., Individualni stečaj, Dosje, Beograd, 2006., str. 1-200.

12 NN, 100/15. od 18. rujna 2015. Sintagma „stečaj“ ima dosta negativne konotacije pa bi vjerojatno naziv zakona, ZSP, trebalo promijeniti, no ostavit ćemo to pitanje po strani iako će se ono svakako morati riješiti u skorijoj budućnosti. 
Slijedi ponovni pokušaj postizanja sporazuma o reguliranju duga u okviru sudskog stečajnog postupka uz mogućnost nametanja rješenja od strane suda kroz tzv. pravila o zabrani opstrukcije (čl. 44.-53. ZSP-a).

Ako u okviru druge etape postupka vjerovnici ne prihvate plan za reguliranje dugova dužnika, slijedi otvaranje postupka stečaja potrošača i likvidacija dužnikove zapljenive imovine u okviru sudskog postupka za koji vrijede pojednostavljena pravila te, ovisno o prijedlogu dužnika, oslobađanje od preostalih dugova tijekom razdoblja do pet godina (tzv. razdoblje dobrog vladanja). Pritom se supsidijarno primjenjuju pravila stečajnog zakona o stečajnim, izlučnim i razlučnim vjerovnicima; vjerovnicima stečajne mase; pravnim posljedicama otvaranja stečajnoga postupka; unovčenju stečajne mase i unovčenju predmeta na kojima postoji razlučno pravo i namirenju stečajnih vjerovnika, osim odredbi o obustavi stečajnog postupka (čl. 53.-59. ZSP-a).

\subsubsection{Normativno trajanje postupka stečaja potrošača i opravdanost analize kroz prizmu konvencijskog prava}

Kako bi se rasteretilo sudove od velikog broja očekivanih postupaka, zakonodavac je predvidio dužnost predlagatelja da pokuša u prvoj fazi postići sporazum sa svojim vjerovnicima u izvansudskom postupku tijekom određenog razdoblja prije podnošenja prijedloga za otvaranje postupka stečaja potrošača nadležnom općinskom sudu (čl. 8. ZSP-a). Svaki stečajni postupak je po svojoj prirodi i zakonskim propisima žuran postupak u cilju očuvanja vrijednosti sredstava i zaštite interesa vjerovnika koji se naplaćuju iz tih sredstava. Stoga i postupak može trajati najdulje 30 dana od dana sastanka navedenoga u pozivu za sudjelovanje. U iznimnim slučajevima, savjetovalište može produljiti rok za dodatnih 30 dana ako ocijeni da postoji mogućnost sklapanja izvansudskog sporazuma između potrošača i svih njegovih vjerovnika ili ako su potrošač i svi njegovi vjerovnici suglasni da se izvansudski postupak produlji. U protivnom izdaje se potvrda da je savjetovanje neuspješno (čl. 18. ZSP-a), a postojanje takve potvrde preduvjet je za pokretanje druge sudske faze.

Sudski postupak stečaja potrošača pokreće se na prijedlog potrošača koji se može podnijeti u roku od tri mjeseca (90 dana) od dana izdavanja potvrde da pokušaj izvansudskog postizanja sporazuma nije uspio (čl. 44. ZSP-a).

Ipak, zakonodavac daje još jednu moguénost potrošaču i vjerovnicima da suglasno poslije pokretanja, a prije otvaranja sudskog postupka, zatraže od suda zastoj, koji može trajati najdulje tri mjeseca (90 dana), u cilju pokušaja sklapanja sporazuma o reguliranju duga. Istekom navedenog razdoblja, postupak se nastavlja ex offo (čl. 46. ZSP-a). 
U svakom slučaju, prije donošenja odluke o otvaranju postupka stečaja potrošača sud će zakazati pripremno ročište na kojem će se raspravljati i glasovati o planu ispunjenja obveza (čl. 47., st. 1. ZSP-a). Vrijeme između objave poziva na mrežnoj stranici e-oglasna ploča sudova za pripremno ročište i pripremnog ročišta ne može biti kraće od 60 dana s tim da je svatko legitimiran izvršiti uvid u popis imovine i obveza i plan ispunjenja obveza u pisarnici nadležnog suda. Poziv za pripremno ročište sadržava poziv vjerovnicima da se očituju na plan ispunjenja obveza u roku od 30 dana od objave poziva za pripremno ročište na mrežnoj stranici e-oglasna ploča sudova. U slučaju da sud ocijeni realnom mogućnost sklapanja sporazuma, ima jednokratnu mogućnost odgoditi pripremno ročište (čl. 47., st. 2. ZSP-a). U svakom slučaju, pripremno ročište započinje razmatranjem plana ispunjenja obveza koji se može na prijedlog pojedinih vjerovnika ili potrošača dopuniti ili izmijeniti. Svaki vjerovnik ima pravo zahtijevati provjeru i dopunu svih tražbina sadržanih u popisu imovine i obveza, pri čemu potrošač ima pravo zahtijevati provjeru svih tražbina koje se naknadno unose u plan na prijedlog vjerovnika. Ako potrošač ili koji od vjerovnika ospori tražbinu vjerovnika, smatrat će se da plan ispunjenja obveza nije prihvaćen (čl. 49. ZSP-a). U protivnome, vjerovnik koji se u roku od 30 dana od objave poziva za pripremno ročište nije izjasnio o planu ispunjenja obveza, smatra se da je dao svoj pristanak na plan. Ako nijedan vjerovnik nije uskratio pristanak na plan ispunjenja obveza, smatra se da je plan prihvaćen. Štoviše, u cilju obustave postupka, potrošač može izmijeniti plan ispunjenja obveza u roku koji odredi sud i s uputama vjerovnika koji je uskratio pristanak na plan ispunjenja obveza. U tom slučaju sud će odgoditi pripremno ročište i ponoviti poziv za pripremno ročište. Stoga, ako dođe do sporazuma, prihvaćeni plan unosi se u zapisnik i ima učinak sudske nagodbe (čl. 50. u vezi s čl. 47., st. 2. ZSP-a). S ciljem sprečavanja opstrukcije od strane nezadovoljnih vjerovnika, sud svojom odlukom može nadomjestiti nedostajući pristanak vjerovnika ako su kumulativno ispunjene sljedeće pretpostavke. Dakle, ako je većina svih vjerovnika prihvatila plan ispunjenja obveza (tzv. personalni kriterij); ako zbroj tražbina vjerovnika koji su dali svoj pristanak prelazi polovinu ukupnih tražbina te ako se vjerovnik koji je uskratio pristanak planom ispunjenja obveza ne dovodi u (ekonomski) lošiji položaj od onoga u kojem bi bio u slučaju otvaranja postupka stečaja potrošača i oslobođenja od preostalih obveza (tzv. imovinski kriterij). Cilj je da nametnuti plan ispunjenja obveza bude uravnotežen i prihvatljiv za većinu vjerovnika jer se ne očekuje da će sve skupine racionalno pristupiti postupku usuglašavanja i prihvaćanja plana. Sud će odluku donijeti nakon što omogući očitovanje vjerovnicima koji su uskratili pristanak na plan ispunjenja obveza, a pritom se dosta nejasno naznačuje kako će se pravni položaj razlučnih vjerovnika posebno raspraviti. Ako plan ispunjenja obveza bude prihvaćen, prijedlog 
za otvaranje postupka stečaja potrošača smatra se povučenim. U protivnom, sud će otvoriti (sudski) postupak stečaja potrošača (čl. 53. ZSP-a).

U slučaju da na pripremnom ročištu plan ispunjenja obveza nije prihvaćen i ako utvrdi postojanje stečajnog razloga, sud će donijeti rješenje o otvaranju postupka stečaja potrošača. Uslijed činjenice otvaranja stečajnog postupka nastaju određene pravne posljedice koje se odnose na pravni položaj subjekata u stečajnom postupku, njihove radnje, druge postupke te pravne poslove (čl. 53. ZSP-a). Rješenje o otvaranju postupka stečaja potrošača mora sadržavati poziv vjerovnicima da povjereniku u roku od 60 dana od dana objave toga rješenja prijave svoje tražbine; poziv razlučnim i izlučnim vjerovnicima da povjerenika u roku od 60 dana od dana objave toga rješenja podneskom obavijeste o svojim pravima; poziv dužnicima potrošača da svoje obveze bez odgode ispunjavaju povjereniku za potrošača te poziv na ispitno ročište i izvještajno ročište (čl. 54., st. 1. ZSP-a). Vrijeme između zadnjega dana roka za prijavljivanje tražbine i ispitnoga ročišta ne smije biti kraće od osam dana ni dulje od dva mjeseca. Izvještajno ročište ne može se održati prije ispitnoga ročišta ni 15 dana od dana održavanja toga ročišta, a postoji mogućnost njihova spajanja tako da se najprije održi ispitno ročište, a zatim izvještajno ročište (čl. 55. ZSP-a). Samo rješenje se ex offo upisuje u javne knjige te se objavljuje na e-oglasnoj ploči suda (čl. 54., st. 2. i 3. SZ-a). Moment objave je ključan jer pravne posljedice otvaranja stečajnoga postupka, kao i u SZ-u, nastupaju u trenutku kad je rješenje o otvaranju stečajnoga postupka objavljeno na mrežnoj stranici e-oglasna ploča sudova, odnosno od točno određenog sata i minute kad je navedeni oglas objavljen (čl. 57., st. 1. ZSP-a). Ako sud na temelju isprava koje se nalaze u sudskom spisu stekne uvjerenje da imovina potrošača koja bi ušla u stečajnu masu nije dovoljna ni za namirenje troškova postupka ili je neznatne vrijednosti, donijet će odluku o otvaranju i zaključenju postupka stečaja potrošača te istodobno imenovati povjerenika i odrediti razdoblje provjere ponašanja u trajanju od pet godina. Povjerenik će nakon zaključenja postupka, u razdoblju provjere ponašanja, u ime i za račun potrošača unovčavati imovinu potrošača i prikupljenim sredstvima namiriti nastale troškove postupka. $\mathrm{O}$ obavljenim radnjama povjerenik je dužan podnositi izvješća sudu. Ako potrošač u razdoblju provjere ponašanja stekne imovinu iz koje se mogu namiriti vjerovnici, na odgovarajući će se način primijeniti odredbe Stečajnog zakona o nastavljanju postupka radi naknadne diobe u slučajevima u kojima se otvoreni stečajni postupak ne provodi (čl. 58. ZSP-a). Prije zaključenja postupka stečaja povjerenik je dužan sastaviti završni diobni popis o kojem se raspravlja na posebnom ročištu. Rok za prigovore vjerovnika iznosi 15 dana od dana objave završnog diobnog popisa, dok će se neobrazložene prigovore odbaciti bez pozivanja podnositelja na njihov ispravak ili dopunu (čl. 68. ZSP-a). Rješenjem o zaključenju postupka stečaja potrošača sud će odrediti 
razdoblje provjere ponašanja koje ne može biti kraće od godinu dana ni dulje od pet godina. Pretpostavka za oslobođenje je provođenje stečaja nad potrošačevom imovinom, unovčenje imovine i namirenje vjerovnika u omjeru u kojemu je to bilo moguće te da je ostalo nenamirenih potraživanja stečajnih vjerovnika. Dodatno se zahtijeva da dužnik sve svoje zapljenive prihode iz narednih nekoliko godina prepusti povjereniku radi naplate preostalih tražbina stečajnih vjerovnika (čl. 71 . ZSP-a). Iznimno, potrošač se neće osloboditi od preostalih obveza i sud neće odrediti razdoblje provjere ponašanja ako potrošač do zaključenja postupka stečaja potrošača izjavi da ne želi oslobođenje od preostalih obveza ili ako je potrošač u posljednjih deset godina koje su prethodile podnošenju prijedloga za otvaranje postupka stečaja potrošača oslobođen od preostalih obveza ili mu je oslobođenje uskraćeno. Samo razdoblje provjere ponašanja počinje teći od pravomoćnosti rješenja o zaključenju postupka stečaja potrošača (čl. 69. ZSP-a). Postupak oslobađanja dužnika od preostalih obveza može se okončati na tri načina. Punim namirenjem stečajnih vjerovnika prije isteka razdoblja dobrog ponašanja, uskratom oslobođenja od preostalih obveza i oslobođenjem dužnika od preostalih obveza. U svakom slučaju sud će donijeti rješenje o oslobođenju ili uskrati oslobođenja od preostalih obveza istekom razdoblja provjere ponašanja. Prije donošenja navedenih odluka, dužan je zakazati ročište na kojem će pribaviti mišljenje vjerovnika, povjerenika i potrošača. $\mathrm{S}$ time da pravo na žalbu protiv rješenja o oslobođenju od preostalih obveza ima svaki vjerovnik koji je predložio sudu donijeti rješenje o uskrati oslobođenja od preostalih obveza, a pravo na žalbu protiv rješenja o uskrati oslobođenja od preostalih obveza potrošač (čl. 74. ZSP-a). Na prijedlog kojega od vjerovnika sud će opozvati određeno oslobođenje potrošača od preostalih obveza ako se naknadno ustanovi da je potrošač koju od svojih dužnosti namjerno povrijedio ili time znatno onemogućio namirenje vjerovnika. Prijedlog se može podnijeti u roku od godinu dana od pravomoćnosti odluke o oslobođenju potrošača od preostalih obveza. Rekli smo da je potrošač podvrgnut posebnom režimu ponašanja tijekom trajanja ustupa, a povreda dužnosti koja sprečava namirenje vjerovnika povlači za sobom kao posljedicu uskratu oslobođenja dužnika od preostalih obveza. Dakle, kako povreda pojedine od navedenih obveza nema istu težinu, na sudu će biti „teret“ da temeljito ispita težinu povrede i objektivne posljedice po mogućnost namirenja. ${ }^{13}$ Kada govorimo o redovnim pravnim lijekovima protiv rješenja donesenoga u prvom stupnju, može se izjaviti žalba u roku od 15 dana od dostave prvostupanjskoga rješenja. Prvostupanjski sud dužan je žalbu podobnu za odlučivanje dostaviti drugostupanjskom sudu u roku od osam dana od njezina primitka. Ako je protiv rješenja dopuštena posebna žalba, prvostupanjski sud će umnožiti dio spisa na koji se žalba odnosi i prijepis toga dijela spisa sa žalbom dostaviti drugostupanjskom

13 Vidi Lovrić, V., op. cit. 
sudu. Dok drugostupanjski sud ne donese odluku, u prvostupanjskom postupku poduzimat će se one radnje koje je moguće poduzimati prije pravomoćnosti pobijanoga rješenja, ako ovim Zakonom nije drukčije određeno. U svakom slučaju žalba nije suspenzivna, a drugostupanjski sud dužan je o žalbi odlučiti najkasnije u roku od 60 dana od primitka žalbe, ako ovim Zakonom nije drukčije određeno. S druge strane, od izvanrednih pravnih lijekova dopuštena je samo tzv. „,izvanredna revizija“ (čl. 27. ZSP-a).

Summa summarum, ZSP inzistira na kratkim rokovima u kojima se donose odluke i usmjeravaju aktivnosti stečajnoga postupka. Štoviše, ideja učinkovitosti i vremenski ograničenog trajanja stečajnog postupka bitna je odlika ZSP-a. Ova se ideja provlači čitavim tekstom i u najvećoj mjeri utječe na relativno kratke rokove koji se daju za ostvarenje pojedinih aktivnosti, pa i za dostavu koja se vrši putem mrežne stranice e-oglasna ploča sudova. Ipak, razdoblje koje treba uzeti u obzir počinje teći od trenutka podnošenja prijedloga za pokretanje izvansudskog postupka stečaja potrošača pa sve do pravomoćnosti sudske odluke o oslobođenju potrošača od preostalih obveza. S obzirom na to da se oslobađanje od dugova odgađa na višegodišnje razdoblje, sasvim je legitimno, a s praktičnog aspekta opravdano i korisno, analizirati praksu ECHR-a u postupcima po čl. 6. Konvencije. Intencija je da se razjašnjavanjem pravnih instituta koji su nastali kao rezultat dugogodišnje prakse i sagledavanjem njihovog međusobnog odnosa dođe do saznanja o pravnologičkom mehanizmu odlučivanja ECHR-a te uvidi predstavlja li nastavno rješenje povredu prava na suđenje u razumnom roku.

\section{PRAVO NA POŠTENO SUĐENJE PREMA ČL. 6. EUROPSKE KONVENCIJE ZA ZAŠTITU LJUDSKIH PRAVA I TEMELJNIH SLOBODA (DALJE: EUROPSKA KONVENCIJA)}

Čl. 6., st. 1. Europske konvencije ${ }^{14}$ glasi: „Radi utvrđivanja svojih prava i obveza građanske naravi ... svatko ima pravo da zakonom ustanovljeni nezavisni i nepristrani sud pravično, javno i u razumnom roku ispita njegov slučaj. ... “ Čl. 6. predstavlja najznačajniju odredbu međunarodnog prava kojom se jamči pravo na pošteno suđenje ključno za ostvarenje vladavine prava. Europski sud primjenjuje metodu autonomnog tumačenja da bi pomirio često vrlo različite koncepte koji postoje u nacionalnim pravima te osigurao jedinstvenu primjenu konvencijskih pravnih pojmova i standarda. U metodi autonomnog tumačenja odražava se „gotovo ustavna priroda Europske konvencije“. Tumačeći konvencijske odredbe,

14 Europska Konvencija za zaštitu ljudskih prava i temeljnih sloboda, NN-MU, 18/97, 6/99, 14/02, $13 / 03,9 / 05,1 / 06$ i $2 / 10$. 
Europski sud odvaguje i utvrđuje postojeće te stvara nove temeljne standarde za skup država ugovornica Europske konvencije. To je posebno značajno za čl. 6. i pravo na pošteno suđenje koje ono jamči. Budući da je to jedno od prava na koje su se podnositelji najviše pozivali pred Europskim sudom, stvorena je vrlo opsežna praksa u pogledu njegova tumačenja. ${ }^{15}$

\subsection{Građanska prava i obveze prema čl. 6. Europske konvencije}

Čl. 6. primjenjuje se u postupcima za utvrđenje građanskih prava ili obveza te će za potrebe ovog rada biti objašnjen pojam građanskih prava i obveza. Naime, Europski sud razvio je opsežnu praksu u tumačenju pojma građanskih prava i obveza iz Europske konvencije. ${ }^{16}$ Tako je samo značenje tih pojmova prema Europskoj konvenciji različito od njihova značenja u nacionalnim pravima. U početku se pojam građanskih prava i obveza određivao preko pojma građanskog prava, praveći tako razliku između privatnog i javnog prava pa su građanska prava i obveze bila prava izvedena iz privatnoga prava. Iz toga proizlazi da Europska konvencija ne jamči pojedincima utvrđivanje svih prava i obveza građanske naravi koja mogu tražiti prema nacionalnom pravu. Međutim, s vremenom je Europski sud sve više i više prava podvodio pod čl. 6. Europske konvencije. S obzirom na dosadašnju praksu Europskog suda možemo zaključiti kako je za primjenu čl. 6. u građanskim predmetima potrebno ispuniti sljedeće uvjete.

Prvo, da je o građanskim pravima i obvezama odlučeno u postupku u kojemu oko sadržaja tih prava i obveza postoji spor. Takav spor mora biti ,izvoran i ozbiljan“. Također mora postojati i rješenje u tom sporu. Taj uvjet znači da ishod spora mora imati „,izravan učinak“ za „građansko pravo“. Odnosno čl. 6. primijenit će se u svim postupcima čiji bi ishod imao izravni učinak na određivanje i/ili stvarni sadržaj građanskog prava ili obveze. Slaba povezanost spora s građanskim pravom ili obvezom kao i neznatne posljedice koje rješenje spora ima za ta prava neće dovesti do primjene čl. 6 .

Drugo mjerilo odgovara na pitanje: Postoji li „pravo“ u smislu čl. 6? Prethodno utvrđeni spor u smislu čl. 6. mora se odnositi na materijalno pravo za koje se može reći da postoji u domaćem pravu tužene države. To drugo mjerilo stvoreno je zbog specifične normativne strukture čl. 6. Europska konvencija ne propisuje nijedno materijalno pravo na koje bi se građanska glava čl. 6. trebala primjenjivati. Stoga je Europski sud u svojoj praksi izgradio pravo da je građanska glava čl. 6. u

15 Podrobnije, Omejec, J., „Konvencija za zaštitu ljudskih prava i temeljnih sloboda u praksi Europskog suda za ljudska prava“", Strasbourški acquis, Novi informator, Zagreb, 2013., str. 1116-1122.

16 Detaljnije, Grbić, S., Pošteno suđenje u građanskim postupcima u Hrvatskoj u svjetlu čl. 6., st. 1. Europske konvencije o ljudskim pravima, Pravni fakultet, Rijeka, 2014., str. 16-29. 
načelu primjenjiva samo na ona materijalna prava koja su priznata u nacionalnom pravu tužene države. Dakle, materijalno pravo o kojem je riječ mora imati pravnu osnovu u domaćem pravu. Europski sud ne smije tumačenjem čl. 6. stvarati novo materijalno građansko pravo koje nema pravnu osnovu u tuženoj državi.

Međutim, budući da može postojati dvojba o tome je li pravo o kojem je riječ priznato na temelju domaćeg prava tužene države ili ne, samo to pitanje podobno je za raspravljanje. Ako se u nekom konkretnom slučaju dogodi da je sporno samo postojanje nekog materijalnog prava u tuženoj državi, a o tom pitanju ovisi primjena građanskog prava prema čl. 6., Europski sud prosuđuje „na osnovama na kojima se može raspravljati“ je li u konkretnom slučaju to pravo bilo priznato u domaćem poretku tužene države ili ne, neovisno o stajalištu same tužene države. ${ }^{17}$

Treći je uvjet postojanje građanskog prava ili obveze. Europski je sud u pojedinim predmetima ustanovio kako je pojam građanskog prava i obveze autonoman i ne može biti tumačen samo prema nacionalnom pravu tužene države. Stoga, ako se pravo u konkretnom predmetu tretira kao dio javnog prava tužene države, ono se za potrebe čl. 6. može smatrati dijelom privatnog prava i obrnuto. Iako je Europski sud prihvatio činjenicu kako pojmovi građansko pravo i obveza imaju samostalno, tj. autonomno značenje unutar Europske konvencije, ipak nije dao točnu definiciju tih pojmova. ${ }^{18}$ Europski sud, dakle, jasno razlikuje materijalna prava koja u svom nacionalnom poretku priznaje tužena država i postupovna prava. ${ }^{19}$

$\mathrm{S}$ tim u vezi mora se ispitati nekoliko čimbenika kako bi se utvrdilo je li neko pravo građansko pravo prema odredbama Europske konvencije:

1.) Bitna je „vrsta samog prava“, a ne njegovo određivanje prema nacionalnom zakonodavstvu. ${ }^{20} \mathrm{U}$ predmetu Ringeisen protiv Austrije ${ }^{21}$ vodio se upravni postupak za registraciju i transakciju zemljišta. Europski sud je utvrdio: „Čl. 6., st. 1. obuhvaća sve postupke čiji je ishod odlučujući za privatna prava i obveze bez obzira na narav propisa koji uređuje kako se neki predmet rješava (građansko, trgovačko, upravno pravo itd.) ili tijela u čijoj je nadležnosti taj predmet (redovni sud, upravno tijelo, itd.).“

2.) Svaki jedinstveni europski pojam o prirodi nekog prava treba razmotriti ${ }^{22}$ pri čemu je važna karakterizacija „vrste samog prava“ unutar prava država

17 Roche protiv Ujedinjenog Kraljevstva, presuda, 19. listopada 2005., br. 32555/96.

18 Harris, D. J., O'Boyle, M., Warbrick, C., Law of the European Convention on Human Rights, Oxford University Press, Oxford, 2009., str. 174-175.

19 Omejec, J., op. cit., str. 723-724.

20 Vidi npr. König protiv Savezne Republike Njemačke, presuda, 28. lipnja 1978., Serija A, br. 27.

21 Ringeisen protiv Austrije, presuda, 16. srpnja 1971., Serija A, br. 13.

22 Feldbrugge protiv Nizozemske, presuda, 29. svibnja 1986., Serija A, br. 99. 
ugovornica. Ako u većini predmeta postoji suglasnost država ugovornica o pravu kao građanskom onda će ga i Europski sud tretirati kao takvo.

3.) Iako je pojam građanskog prava autonoman, Europski sud smatra kako nacionalno pravo nije nevažno, čak ni kada ne postoji suglasnost među državama ugovornicama. U predmetu König protiv Savezne Republike Njemačke ${ }^{23}$ Europski sud utvrdio je sljedeće: „Kako bi se utvrdilo spada li pravo pod građansko prema značenju koje mu daje Europska konvencija potrebno je ispitati njegov materijalni sadržaj i učinke tog prava, a ne njegovu pravnu klasifikaciju u domaćem pravu države u pitanju." Primjerice, pitanje potpada li pravo obavljanja liječničke prakse pod javno ili privatno pravo ovisi o činjenici jesu li takve usluge u tuženoj državi dio javnih službi ili se ključna pitanja uređuju ugovorom između liječnika i pacijenta. Na taj način, usprkos autonomnoj prirodi građanskih prava i obveza, ista prava i obveze u jednom pravnom sustavu potpadali bi pod čl. 6., dok prema pravnom sustavu druge države ugovornice to ne bi bilo moguće. Iz toga je vidljivo kako Europski sud, odlučujući potpada li određeno pravo pod građansko ili ne, ispituje sve okolnosti pojedinog predmeta pa kada se govori o pojmu građanskih prava i obveza u smislu čl. 6. najjednostavnije je navoditi primjere u kojima je Europski sud utvrdio da pojedino pravo potpada ili ne potpada pod taj pojam.

\subsubsection{Potrošačko stečajni postupak kao predmet odlučivanja o građanskim pravima i obvezama (dužnika i vjerovnika)}

Iako je u predmetu Ismeta Bačić protiv Hrvatske ${ }^{24}$ Vlada RH tvrdila kako se čl. 6., st. 1. Konvencije ne primjenjuje na stečajni postupak budući da on nije sporni postupak te da u takvom postupku sudovi ne presuđuju o zahtjevima stranaka, već samo utvrđuju imovinu stečajnog dužnika, Europski sud je naznačio kako je primjenjivost čl. 6., st. 1. Konvencije na stečajni postupak neupitna. ${ }^{25}$

23 König protiv Savezne Republike Njemačke, presuda, 28. lipnja 1978., Serija A, br. 27.

24 Ismeta Bačić protiv Hrvatske, presuda, 19. lipnja 2008., br. 43595/06.

25 Arg., S.p.r.1. ANCA and Others protiv Belgije, odluka, 10. prosinca 1984., Decisions and Reports 40, Interfina and Christian della Faille d'Huysse protiv Belgije, odluka, 4. svibnja 1987., br. 11101/84, Ceteroni protiv Italije, presuda, 15. studenoga 1996., Reports of Judgments and Decisions 1996-V, Bassani protiv Italije, presuda, 11. prosinca 2003., br. 47778/99, Capital Bank AD protiv Bugarske, presuda, 24. studenoga 2005., br. 49429/99 i Sukobljević protiv Hrvatske, presuda, 2. studenoga 2006., br. 5129/03. Vidi i predmet Back protiv Finland, presuda, 20. srpnja 2004., zahtjev br. 37598/97. gdje se raspravljalo o položaju jamca u postupku potrošačkog stečaja. 


\subsection{Pravo na pošteno suđenje u razumnom roku prema čl. 6. Konvencije}

Razlog zbog kojega se najčešće poziva na povredu čl. 6. jest trajanje postupka preko ,razumnog roka“. Samo o tom pitanju doneseno je više presuda negoli i za jedno drugo koje jamči Europska konvencija. Stranke se zbog povrede razumnog roka mogu obraćati Europskom sudu bilo tijekom trajanja postupka za koji smatraju da predugo traje ili nakon završenog postupka (čak i ako su izgubile spor), pri čemu je važno da je to rok od šest mjeseci nakon donošenja pravomoćne odluke.

Pri odlučivanju o tomu je li postupak predugo trajao, prvo je nužno utvrditi vremensko razdoblje u kojem se taj postupak odvijao. U vezi s određivanjem građanskih prava i obveza, kao početak razdoblja može se općenito uzeti trenutak kada je taj postupak pokrenut, ${ }^{26}$ ili u kojemu su, u okviru drugih postupaka, takvo pravo ili obveza spomenuti u obrani. Ako je prije sudskog postupka neka druga radnja, npr. upravna tužba ${ }^{27}$ ili zahtjev za formalnom potvrdom morao biti iznesen, početak se pomiče na trenutak te radnje. Također, Europski sud u predmetu Erkner $i$ Hofauer protiv Austrije ${ }^{28}$ zaključio je: „U građanskim postupcima, ,razumni rok“ iz čl. 6., normalno počinje teći u trenutku kada je pokrenut postupak pred sudom; međutim, u određenim situacijama, to vrijeme, eventualno, može početi teći i ranije.“

Kraj razdoblja, koje treba uzeti u obzir, trenutak je u kojemu je sud okončao neizvjesnost u vezi s pravnim položajem dotične osobe. Kada je riječ o građanskom postupku, to je trenutak kada se na najvišoj instanci donese odluka ili kada je ona postala konačna istekom žalbenog roka. Europski sud je u presudi Erkner i Hofauer protiv Austrije iznio sljedeći zaključak glede određivanja završetka razdoblja o kojem je riječ: „Period o čijem se razumnom trajanju raspravlja obuhvaća cjelokupni postupak, uključujući i postupke povodom žalbe. Tako se taj period produžuje sve do donošenja odluke koja rješava dotični spor." ${ }^{\text {29 }}$

Kada se odredi duljina relevantnog razdoblja, mora se odlučiti treba li to razdoblje smatrati razumnim. Nužno je naglasiti da Europski sud, kada ispituje predmete koji su se vodili nakon što je u određenoj državi Europska konvencija stupila na snagu, uzima u obzir i stanje predmeta na dan kada je Europska konvencija u toj državi stupila na snagu. Kada je riječ o Republici Hrvatskoj, Europska konvencija stupila je na snagu 5. studenoga 1997. Tako možemo reći da se za procjenu razumnog roka

26 Vidi, primjerice, Scopelliti protiv Italije, presuda, 23. studenoga 1993., Serija A, br. 278.

27 Konig protiv Njemačke, presuda, 28. lipnja 1987., Serija A, br. 27.

28 Erkner i Hofauer protiv Austrije, presuda, 23. travnja 1987., Serija A, br. 117.

29 Dutertre, G., van der Velde, J., Key extracts from a selection of judgements of the European Court of Human Rights and decisions and reports of the European Commission of Human Rights, Brusseles, Council of Europe, 1999., str. 84-85. 
uzima u obzir i stadij u kojem se sudski postupak našao u tom trenutku, odnosno koliko dugo se postupak vodio do navedenog datuma.

Da bi postupak bio pošten, treba biti proveden u razumnom roku, a u predmetu Zimmermann i Steiner protiv Švicarske ${ }^{30}$ Europski je sud dao sljedeći kriterij za njegovo određivanje:

„Razumni rok, u okviru kojeg se mora provesti postupak i koji potpada pod čl. 6., st. 1. Europske konvencije, mora se odrediti u svakom pojedinom slučaju prema okolnostima toga predmeta. Europski sud mora uzeti u obzir složenost činjeničnih i pravnih pitanja, ponašanje podnositelja i nadležnog tijela i značaj predmeta za podnositelja ...". ${ }^{31}$ Iz toga proizlazi da pri procjenjivanju razumnosti relevantnog razdoblja, Europski sud posebno razmatra sljedeće čimbenike:

1. složenost predmeta,

2. ponašanje podnositelja,

3. ponašanje nadležnih vlasti i

4. važnost predmeta spora za podnositelja.

\subsubsection{Analiza potrošačko-stečajnog postupka kroz standarde razumnosti relevantnog razdoblja}

Za učinkovito pružanje pravne zaštite u građanskim stvarima u pravilu su potrebne dvije komponente: učinkovit građanski postupak u kojem će se utvrditi sadržaj prava te učinkovit sustav provedbe odluke u kojem će se izvršiti odluka donesena u građanskom sudskom postupku. U proteklom desetljeću sazrelo je i shvaćanje da su za temeljno procesno ljudsko pravo, pravo na pošteno suđenje prema čl. 6. Europske konvencije jednako konstitutivni i dobro uređen sustav suđenja (meritornog odlučivanja o osnovanosti zahtjeva) i djelotvoran sustav egzekucije sudskih odluka. ${ }^{32}$ Stoga čl. 6. obuhvaća i postupke koji se vode nakon suđenja kao što je postupak generalne egzekucije odnosno stečajni postupak.

\subsubsection{Složenost predmeta potrošačko-stečajnih postupaka}

Općenito je teško govoriti o pravnoj složenosti ili jednostavnosti predmeta. U praksi Europskog suda, pa i Ustavnog suda RH, ovaj standard nije definiran na opći način, već se promatra kazuistički. Ipak, Europski

30 Zimmermann i Steiner protiv Švicarske, presuda, 13. srpnja 1983., Serija A, br. 66.

31 Dutertre, G., van der Velde, J., op. cit., str. 83.

32 Uzelac, A., „Kako organizirati efikasno izvršenje nespornih tražbina - neka komparativna iskustva“, Zbornik Konferencije Kako unaprijediti izvršni postupak u BiH, Sarajevo, 2009. Dostupno na mrežnim stranicama: www.hjpc.ba/pr/msword/PR0AlanUzelac.doc (22. siječnja 2016.). 
sud je, ispitujući složenost predmeta, stvorio određene smjernice kojima se rukovodi pri odlučivanju je li postupak trajao preko razumnog roka. Tako je iznio kako su sve okolnosti predmeta relevantne u procjeni njegove složenosti. U prvom redu prosuđuje se složenost predmeta, bilo u postupovnom smislu ili s obzirom na meritum samog spora. Tako će, primjerice, Europski sud uzeti u obzir činjenicu da je predmet u određenom razdoblju razmatralo više sudova, a ne samo jedan, što znači kako nije ista situacija je li postupak trajao sedam godina pred jednom instancom ili pred tri instance. ${ }^{33}$ Ispitivanje složenosti predmeta odnosi se i na činjenična i pravna pitanja: prirodu i težinu tih pitanja povodom kojih se vodi spor; prirodu činjenica koja treba ustanoviti broj pitanja o kojima se mora odlučiti u pojedinom slučaju; ispitivanje prostorne ili vremenske udaljenosti između događaja ili činjenica o kojima je riječ; broj svjedoka i drugih pitanja koja se postavljaju prilikom sakupljanja dokaza; javljanje potrebe da se pribavi spis sa suđenja koje je obavljeno u drugoj državi, tj. međunarodni elementi; povezanost s drugim predmetima; intervencija drugih osoba u postupku, et seq. Govoreći o postupku potrošačkog stečaja, s jedne strane, moglo bi se tvrditi da se radi o pravno jednostavnijim predmetima, ali s druge strane ta se tvrdnja opovrgava ako uzmemo u obzir da se u potrošačkostečajnom postupku supsidijarno primjenjuju pravila SZ-a, ${ }^{34}$ Ovršnog zakona, ${ }^{35}$ Zakona o parničnom postupku, ${ }^{36}$ Zakona o obveznim odnosima ${ }^{37}$ kao i Zakona o vlasništvu i drugim stvarnim pravima ${ }^{38}$ koja su iznimno

33 U predmetu Zimmermann i Steiner protiv Švicarske, presuda, 13. srpnja 1983., Serija A, br. 66., poprilično kratko razdoblje od tri i pol godine smatrano je predugim za žalbeni postupak pred Upravnim sudom gdje postoji jedna jedina sudska instanca, a nisu poduzeti odgovarajući koraci u rješavanju problema nagomilavanja predmeta.

34 Primjerice, neosporni je interes da se (svaki) stečajni postupak, u želji postizanja učinkovite procedure, okonča u razumnom (hitnom) roku. Ipak, problem razumnog roka stečajnog postupka za sobom povlači još jednu posljedicu, tj. delikatnost odnosa dužnika i vjerovnika koja je konstantno prisutna u pravu, a koja se ogleda i u pravu na pobijanje dužnikovih pravnih radnji. Naime, cilj svakog pobijanja u konačnici je uvijek isti - obogatiti stečajnu masu i time maksimalizirati iznos namijenjen za razmjernu distribuciju vjerovnicima. Razloga za pobijanje gotovo uvijek ima u svakom stečajnom postupku zbog toga jer je dužnik prije stečaja, ali i za vrijeme insolventnosti, poduzimao određene radnje kojima je pogodovao pojedinim vjerovnicima, odnosno kojima je druge vjerovnike oštetio u namirenju. Stoga nemogućnost utjecaja na razumno trajanje postupaka u sporovima u kojima dužnik nije strana u sporu, a koji mogu proizaći iz stečaja, svakako predstavljaju nerazrješiv problem ostvarenja načela hitnosti postupanja.

35 NN, 112/12., 25/13., 93/14.

36 NN, 53/91., 91/92., 112/99., 129/00., 88/01., 117/03., 88/05., 2/07., 96/08., 84/08., 123/08., 57/11., 25/13., 89/14.

37 NN, 35/05., 41/08., 125/11., 78/15.

38 NN, 91/96., 68/98., 137/99., 22/00., 73/00., 114/01., 79/06., 141/06., 146/08., 38/09., 153/09., 90/10., 143/12., 152/14. 
kompleksna u materijalnopravnom i procesnopravnom smislu. Složenosti predmeta doprinosi i činjenica da predmeti mogu dobiti i međunarodni/ nadnacionalni element pa, bez obzira na entuzijazam koji se uočava u dijelu pravne literature, usklađivanje prava u praksi kada se radi o potrošačkom stečaju s međunarodnim elementom pokazuje se kao naporan i usporen proces, posebno na europskoj razini. ${ }^{39}$ Dakle, pozivanje vlasti na složenost slučaja bit će uspješno samo ako one mogu dokazati da tijek dotičnog postupka nije doveo do povrede razumnog roka iz čl. 6. odnosno predmet koji je vrlo složen može ponekad opravdati dugotrajan postupak. ${ }^{40}$ Svakako treba spomenuti da će u ovakvoj osjetljivoj vrsti predmeta biti, uz niz pravnih pitanja, i mnogo faktičnih (socijalnih, socioloških i ekonomskih) pitanja. Ipak uslijed opsega problematike nismo u mogućnosti obraditi kompleksnost cijelog postupka pa smo se fokusirali samo na jedan problem, a to je pitanje prava na dom. Naime, zakonodavac zadnjom novelom $\mathrm{OZ}^{41}$ nije iskoristio svoje pravo ili bolje rečeno nije ispunio svoju obvezu da odredi da se od ovrhe izuzme nekretnina koja predstavlja jedini dom ovršenika. ${ }^{42}$ Stoga je pitanje doma u postupku potrošačkog stečaja postalo osjetljivo iz više razloga. Prije svega pravnih jer se u postupku stečaja potrošača primjenjuju pravila ovršnog ograničenja odgovornosti, dakle pravila Ovršnog zakona. Pritom trebamo biti svjesni kako naša sudska praksa nije osposobljena da se po hitnom postupku transformira od prakse ,pozitivizma“ u praksu „kreativizma“, no ipak mora prihvatiti činjenicu da se, preko Europskog suda, afirmira načelo precedentalnog prava i time sudske prakse kao formalnog izvora prava, što zahtijeva pojačanu pozornost u praćenju i tog

39 Vidi Bodul, D., Vuković, A., „Prilog raspravi o uvođenju potrošačkog stečaja: neka pitanja potrošačkog stečaja s međunarodnim/prekograničnim elementom“, Hrvatska pravna revija, 2013., br. 7-8, str. 61-67.

40 Grbić, S. op. cit., str. 67-68.

${ }^{41}$ NN, 93/14. Podrobnije, Mihelčić, G. u suradnji s Kontrec, D., Komentar Ovršnog zakona s opsežnom sudskom praksom i abecednim kazalom pojmova, Organizator, Zagreb, 2015., str. 350-500.

42 Za spomenuti je da se najznačajnije promjene odnose na ovrhu na nekretnini. Naime, prodaju nekretnine sada provodi Financijska agencija, čija je nadležnost za provedbu ovrhe određena novim čl. 132., a OZ prema kojem se zahtjev za prodaju i ostala pismena u postupku prodaje nekretnina dostavljaju regionalnim centrima Agencije čija se mjesna nadležnost utvrđuje prema nadležnosti suda koji provodi ovrhu, dakle suda na čijem se području nekretnina nalazi. Podrobnije, Kontrec, D., Ovrha na nekretnini, izlaganje sa skupa Hrvatska gospodarska komora - Sektor za trgovinu, 23. forum poslovanja nekretninama. Materijali dostupni kod autora. 
izvora prava, konkretno čl. 8. Konvencije ${ }^{43}$ i koncepta prava na dom. ${ }^{44}$ In ultima linea, pitanje i problematika prava na dom suviše su kompleksni, vremenski i prostorno, političko-ekonomski i institucionalno senzibilni, pa bi analiza zahtijevala znatno širi prostor. No treba istaknuti da sukladno ZSP-u sud može, na zahtjev dužnika i pod određenim pretpostavkama, odgoditi prodaju nekretnina tijekom razdoblja provjere ponašanja koja je dužniku potrebna za stanovanje. Na taj način sudovima se omogućuje da legitimno svojim odlukama formuliraju socijalnu politiku, čime više ne trebaju brinuti isključivo za presuđivanje pravnih sporova, već im je cilj stvaranje društvene politike odnosno imaju mogućnost zahvatiti mnogo više ljudi nego je to slučaj u rješavanju pojedinačnog slučaja (tzv. sudski aktivizam) ${ }^{45}$ No problem tu ne staje, iako sud može odobriti odgodu prodaju nekretnine tijekom razdoblja provjere dobrog ponašanja, nakon istog slijedi prodaja nekretnine po pravilima ovršnog postupka koja, iako su najopsežnija i najrazrađenija, u primjeni ukazuju na nedjelotvornost sustava pružanja ovršno-pravne zaštite. Štoviše, teorija ukazuje kako na sudovima u Republici Hrvatskoj postoje tisuće predmeta, neki još iz vremena važenja Zakona o izvršnom postupku, ${ }^{46}$ koji prije svega „stoje“ na pitanju provedbe ovrhe, odnosno konačnog prisilnog ostvarenja tražbine vjerovnika uslijed čega je ECHR našao RH objektivno odgovornom u mnogim slučajevima, iako sama nije jedna od stranaka u sporu, jer država je ta koja mora osigurati djelotvorno funkcioniranje pravosudnog sustava. Nadalje, pitanje prisilnog iseljenja potrošača iz „doma“ „osjetljivo“ je iz niza faktičnih razloga, pa tako iz socijalnih razloga jer se dužniku može prodati kuća ili stan u kojem stanuju, zbog ekonomskih razloga, jer su vrijednosti nekretnina uvijek veće od nekih drugih predmeta ovrha, pa

43 Pravo na poštovanje privatnog i obiteljskog života:

1. Svatko ima pravo na poštovanje svoga privatnog i obiteljskog života, doma i dopisivanja.

2. Javna vlast se neće miješati u ostvarivanje tog prava, osim u skladu sa zakonom i ako je u demokratskom društvu nužno radi interesa državne sigurnosti, javnog reda i mira, ili gospodarske dobrobiti zemlje, te radi sprečavanja nereda ili zločina, radi zaštite zdravlja ili morala ili radi zaštite prava i sloboda drugih.

44 Sintagma „dom“ autonoman je pojam u okviru značenja čl. 8., st. 1. Europske Konvencije za zaštitu ljudskih prava i sloboda. U francuskoj inačici teksta koristi se izraz ,domincile koji ima puno šire značenje od engleskog pojma home. Prema praksi Europskog suda domom se smatra fizički definirani prostor gdje se razvija privatni i obiteljski život. Podrobnije, Harris, D. J., O’Boyle, M., Warbrick, C., op. cit., str. 376.

45 Vidi Bačić, A., „O sudskom aktivizmu ili o političkoj ulozi sudova“, Politička misao, vol. 35, 1998., no. 2, str. 106. et seq.

46 NN, 53/91. i 91/92. 
i zbog socioloških jer se prodajom nekretnina u kojima dužnici stanuju stvaraju beskućnici, odnosno osobe koje moraju iznajmljivati stanove. ${ }^{47}$ Neki od ovih razloga veoma su specifične i kompleksne prirode i praktično mogu postati predmet obrade nekog drugog rada ove ili slične vrste, pa ih zbog toga svakako nije moguće u potpunosti analizirati. ${ }^{48}$

\subsubsection{Ponašanje podnositelja prijedloga za pokretanje postupka potrošačkog stečaja}

Ponašanje samoga podnositelja također se uzima u obzir u praksi Europskog suda pri odlučivanju o tomu je li postupak trajao preko razumnog roka. Ako on oteže s postupkom, to neće pasti na teret i na odgovornost države. Podnositelj, međutim, ima pravo iskoristiti sve postupovne mogućnosti koje mu pružaju zakoni, i to se samo po sebi neće smatrati produženjem postupka. Naprotiv, ako podnositelj odbija suradnju s vještakom, ako ne želi prihvatiti nadležnost određenog suda itd., Europski sud može zaključiti da je podnositelj sam pridonio trajanju postupka. Ako podnositelj nastoji ubrzati postupak, to će ići u njegovu korist, ali propust podnošenja zahtjeva za ubrzanjem postupka neće automatski dovesti do povrede prava na pošteno suđenje u razumnom roku zbog ponašanja podnositelja. Dakle, općenito je prihvaćeno da u građanskim postupcima zainteresirana strana mora pokazati dužno poštovanje u vođenju postupka i ne odugovlačiti postupak ${ }^{49} \mathrm{ZSP}$ isključuje administrativno ovlaštenje za pokretanje stečajnog postupka i jasno definira tko može biti predlagatelj, odnosno predlagatelji. Izvansudski postupak pokreće se zahtjevom koji može podnijeti potrošač ili svaki njegov vjerovnik (čl. 12. ZSP-a) dok se sudski postupak stečaja potrošača pokreće isključivo na prijedlog potrošača (čl. 44. ZSP-a). Ipak, uvođenjem modela potrošačkog stečaja u zakonodavstva postoji rizik od lako dostupnog otpusta dugova koji bi ohrabrivao nepoštene dužnike da svjesno naprave znatne dugove bez namjere njihove otplate. Stoga, kako se potrošački stečaj i slični postupci mogu zlorabiti, nužan je zaštitni element pa je zakonodavac pri implantaciji odredbi potrošačkog stečaja napravio

47 Kontrec, D., op. cit.

48 Vidi, primjerice, Jacoby, M. B., „Collecting Debts from the Ill and Injured: The Rhetorical Significance, But Practical Irrelevance, of Culpability and Ability to Pay“, American University Law Review, vol. 51, 2001., br. 1, str. 250-266; Feibelman, A., „Defining the Social Insurance Function of Consumer Bankruptcy“, American Bankruptcy Institute Law Review, vol. 13, 2005., str. 129-130; Flint, R. E., „Bankruptcy Policy: Toward a Moral Justification for Financial Rehabilitation of the Consumer Debtor“, Washington and Lee Law Review, vol. 48, 2001., br. 1, str. 529. te Halpern, S.W., „Application of the Doctrine of Commercial Impracticability: Searching for The Wisdom of Solomon“, University of Pennsylvania Law Review, vol. 135, 1987., br. 1, str. 1123. i 1159.

49 Grbić., S., op. cit., str. 69-70. 
veliki iskorak, što je primjerice propustio učiniti u korporativnom stečaju, ${ }^{50}$ određujući da samo pošteni potrošač može ishoditi otpust dugova. To je bitno jer sprečava zloporabu postupka od nepoštenog dužnika koji želi izbjeći plaćanje svojih dospjelih obveza. Pretpostavka je da je dužnik djelovao pošteno kada je pao u stanje insolventnosti. Takva presumpcija zahtijeva od dužnika potpuni prikaz imovinskog stanja, odnosno imovine i prihoda kada postane stranka u potrošačkostečajnom postupku. Njime se želi utvrditi i očuvati prihvatljive standarde ponašanja u poslovanju, primjerice, načelo savjesnosti i poštenja, zabranu zloupotrebe prava, dužnost ispunjenja obveze te zabranu prouzrokovanja štete te se razmatra tijekom cijelog postupka (čl. 2., st. 1., reč. 1. te čl. 75., st. 1., t. 4. ZSP-a). Štoviše, poštenje potrošača utvrđuje sud uzimajući u obzir ne samo prije podnošenja prijedloga za otvaranje postupka stečaja potrošača već se uzima u obzir i njegovo ponašanje tijekom sudskoga postupka i razdoblja provjere ponašanja. Potencijalni problem koji se može javiti vezan je za nomotehničke nejasnoće odnosno za nejasne pravne standarde temeljem kojih sud može uskratiti otpust dugova. ${ }^{51}$ Doktrina smatra kako će se tolerirati blaga lakomislenost dužnika u gospodarenju i postupanju sa svojom imovinom, ali neki od razloga zahtijevat će tumačenja i stvaranja određenih standarda nepoželjnih ponašanja dužnika koja priječe sud da odobri otpust dugova okončanjem razdoblja dobrog ponašanja.

\subsubsection{Ponašanje nadležnih vlasti odnosno tribunala}

Iako je potreba za proširenjem pasivne stečajne sposobnosti na sve fizičke osobe sagledana odavno, a uzroci koji su na to ukazivali nisu došli neočekivano, cijeli proces implementacije potrošačkog stečaja u pravni poredak u Republici Hrvatskoj s institucionalnog aspekta kretao se iznimno sporo. Štoviše, uz Italiju, mi smo zadnja zemlja koja je implementirala navedeni institut. Ipak prvo je pitanje treba li postupak stečaja potrošača u prvoj fazi staviti u nadležnost izvansudskih tijela, odnosno FINA-e i drugih odgovarajućih osoba. Naime, dosadašnja su iskustva s FINA-om u korporativnom stečaju, kao tijelom postupka, negativna pa novi SZ, koji se supsidijarno primjenjuje u postupku potrošačkog stečaja, određuje da je FINA tijelo koje djeluje po uputama suda, no ipak pojam uputa nije definiran, a mišljenja smo kako sudac ne može davati upute jer tijelo kao FINA koje sudjeluje u postupku temeljem zakona mora znati primjenjivatiZakon. ${ }^{52}$ Analizirajuću sudski dio postupka

50 Judikatura smatra da je trebao biti definiran pošteni poduzetnik u novom SZ-u koji je trebao biti predmet postupanja sudova, cijelog popratnog mehanizma koji iznimno puno košta i treba donositi rezultate. Radić, N., „Predstečajni postupak“, materijali sa savjetovanja Dani hrvatskog insolvencijskog i ovršnog prava, održanog u Zagrebu, 21. siječnja 2016., organizator pravni portal IUS INFO.

${ }^{51}$ Lista daje široki spektar razloga za uskratu oslobođenja. Vidi čl. 75. ZSP-a.

52 Pritisak za jaču ulogu suda u predstečajnim nagodbama vršila je i primjena čl. 6. iz Europske konvencije za zaštitu ljudskih prava i temeljnih sloboda. Praksa ECHR-a naznačuje kako se čl. 6., st. 1. 
stečaja potrošača, a zbog činjenice da primjena pred sudovima u fazi pisanja ovog rada još nije formalno počela, teško je govoriti o potencijalnom ,ponašanju“ sudova. Naravno, iz prethodno rečenoga vidimo da je sudska nadležnost u ovom postupku rezultat težnji da se dosljedno ostvari načelo jednakosti vjerovnika, tzv. načelo par conditio creditorum est $\mathrm{i}$ zaštiti dostojanstvo dužnika. Ipak, činjenica da je postupak stavljen u stvarnu nadležnost općinskih, a ne trgovačkih sudova, koji tradicionalno vode ovu vrstu postupaka, može biti indikativna jer je pitanje hoće li sudovi koji nisu specijalizirani za ovu vrstu predmeta biti u stanju iste adekvatno i provoditi. Navedeno posebno dolazi do izražaja ako analiziramo razloge zašto su postupci stavljeni u nadležnost općinskih sudova. ${ }^{53}$ Dakle, razlozi delegiranja nadležnosti na općinske sudove pragmatične su, a ne stručne prirode. Naime, danas, u 21. stoljeću, možemo konstatirati da objektivna potreba za specijalizacijom sudova nije nikakav hir niti pragmatičnost, već nužan rezultat zahtjeva za učinkovitom, u konkretnom slučaju, stečajnopravnom sudskom zaštitom. Štoviše, stečajni postupak je zbog specifičnih poslovnih standarda i pravila postao iznimno zahtjevna materija pa teorija i praksa govore o potrebi formiranja posebnih „stečajnih“ sudova. U navedenom kontekstu Europska konvencija obvezuje države ugovornice na organiziranje svojih pravosudnih sustava na način koji omogućava rad sudova u skladu sa zahtjevima iz čl. 6., st. 1., uključujući i zahtjev za vođenjem postupaka u „razumnom roku“. Privremena opterećenost sudstva ne utječe na tu obvezu države, ako one brzo poduzmu potrebne korake kojima bi riješile takve situacije. Prema tome, države ugovornice nisu odgovorne u slučaju privremenog zaostatka svojih

primjenjuje na stečajni postupak pa prva dvojba koja se odnosi na samu legitimnost procesa dejudicijalizacije kroz model predstečajne nagodbe i ulogu FINA-e jest činjenica da stečajnopravna zaštita mora biti u nadležnosti onog tijela koje Konvencija označava sintagmom „tribunal“ (bez obzira na to kojoj vlasti pripada), a danas ta svojstva u pozitivnom pravu ima samo sud (Stran Greek Refineries i Stratis Andreadis protiv Grčke, presuda, 9. prosinca 1994., Serija A, br. 301-B). To je rezultiralo „,brisanjem“ zakonodavnih rješenja po kojima je FINA de facto i de jure odlučivala u postupcima predstečajne nagodbe. Vidi Barbić, J. (ur.), Hrvatsko insolvencijsko pravo, Hrvatska akademija znanosti i umjetnosti, Znanstveno vijeće za državnu upravu, pravosuđe i vladavinu prava, Zagreb, 2014., str. 1-227.

53 Trgovački su sudovi u 2015. zaprimili 19.543 stečajna predmeta, a riješili samo 5.255, što predstavlja svega 26,9 \% riješenih predmeta u odnosu na primljene. Navedeno je posljedica zadnjih izmjena, odnosno novoga SZ-a. Doktrina ukazuje kako iz statističkih podataka jasno proizlazi da predlagač Zakona nije predvidio učinke i posljedice koje će zakonske izmjene proizvesti te uslijed toga nije ni pripremio pravosudni sustav da spremno dočeka povećani priljev stečajnih predmeta. Pri tome se u 2016. očekuje daljnji rast priljeva stečajnih predmeta kao izravna posljedica izmjena SZ-a te je stoga potrebno hitno poduzeti korektivne mjere kako bi se trgovački sudovi mogli nositi s ovako povećanim priljevom predmeta. Opterećenost sudaca u tim predmetima povećala se na 1.651 predmet po sucu, što na neki način otkriva razloge povećanja zaostataka. Tako i podrobnije, Turkalj, K., „Kako pravosuđe može dati doprinos gospodarskom rastu u Republici Hrvatskoj“, Pravo i porezi, 2016., br. 4, str. 59. et seq. Postavlja se pitanje može li sadašnja organizacija trgovačkih sudova podnijeti „,teret“ vođenja pet vrsta insolvencijskih postupaka - predstečajnih nagodbi, predstečajnih postupaka, stečajnih postupaka, skraćenih stečajnih postupaka i tzv. automatskih stečajeva. Također, ne smije se izgubiti iz vida da su trgovački sudovi, sukladno odredbama novog Stečajnog zakona, postali i ,ovršni“ sudovi, a za pretpostaviti je da će sve u konačnici rezultirati i sporovima pred višim sudovima, dakle pred Vrhovnim sudom kao i Visokim trgovačkim sudovima, što će dodatno opteretiti sustav trgovačkog pravosudstva i postaviti pitanje održavanja standarda „razumnog roka“ provođenja korporativnih stečajnih postupaka. 
sudova, pod uvjetom da odmah poduzmu radnje da se popravi takva izvanredna situacija. Poduzete mjere procjenjuju se u odnosu na njihovu djelotvornost, a procjenjuje se i jesu li poduzete pravodobno. ${ }^{54}$ Mjere poduzete kasnije ne mogu promijeniti činjenicu prekoračenja razumnog roka. Kada to procjenjuje, Europski sud je spreman uzeti u obzir političke i društvene prilike zemlje. Europski sud u takvim situacijama smatra da je neprimjereno svako produživanje postupaka izvan onoga što se može smatrati razumnim rokom. Tako je Europski sud smatrao kako do takvih kašnjenja dolazi ako previše vremena prođe do donošenja presude ili ako se odgađaju saslušanja zbog toga što suci rješavaju istodobno velik broj predmeta, pa se preopterećenost sudstva općenito ne prihvaća kao opravdanje duljine postupka i dovodi do povrede prava na pošteno suđenje u razumnom roku zbog ponašanja nadležnih vlasti. Europski sud je ovdje istaknuo kako nastojanja sudske vlasti da što brže provedu postupak, imaju vrlo važnu ulogu. U tom smislu na sudu leži posebna dužnost osiguranja da sve osobe u postupku daju maksimum kako bi se izbjegla nepotrebna kašnjenja, jer država je odgovorna za svako trajanje postupka koje se pripisuje njezinim sudskim i upravnim tijelima. Tu se, gotovo matematički, uzimaju u obzir razdoblja neaktivnosti sudova. Neaktivnost ne znači samo neodržavanje rasprave, već izostanak bilo kojih postupovnih radnji kroz dulje razdoblje. Takvu pasivnost Europski sud strogo sankcionira.

\subsubsection{Važnost predmeta spora za insolventnog potrošača}

Sa stajališta potrošačkog stečaja, promišljanje o ljudskom dostojanstvu osobito je zanimljivo budući da je u njegovu središtu čovjek, pojedinac i njegov ,život u insolvencijskom režimu“. Premda apstraktan i filozofski, pojam dostojanstva za nas je bitan zbog njegove socijalno egzistencijalne komponente. Europska konvencija, o kojoj je riječ u ovom radu, preuzela je načela iz Opće deklaracije o pravima čovjeka, ${ }^{55}$ dodatno ih razradila i dodala specifičan mehanizam nadzora provođenja prava zajamčenih Konvencijom. Međutim, iako je Europska konvencija najznačajniji korak za pojedinca u priznavanju međunarodnog subjektiviteta, $\mathrm{u}$ Konvenciji se izrijekom ne navodi ljudsko dostojanstvo. Ipak praksa Europskog suda ukazuje na to da je vrlo bitan čimbenik koji se mora uzeti u obzir pri određivanju razumnosti trajanja postupka, važnost predmeta spora za podnositelja, pa možemo tvrditi i njegovo dostojanstvo. Tako, kada je riječ o određenim pitanjima, Europski je sud utvrdio da nacionalni sudovi moraju postupati s još više dužne pažnje i još učinkovitije. To je potvrđeno u predmetima u kojima se raspravljalo o obiteljskim i statusnim odnosima, starateljskim odnosima, radnim odnosima. Tu spadaju i sporovi

\footnotetext{
54 Vidi Guincho protiv Portugala, presuda, 10. srpnja 1984., br. 8990/80.

55 NN-MU, 12/09.
} 
vezani uz mirovinu, osobito ako je podnositelj poodmakle dobi. U tu kategoriju spadaju, zatim, slučajevi u kojima se raspravlja o građanskom statusu i položaju, tj. statusni predmeti, a i stečajni postupci. U takvim slučajevima traži se „posebna pažnja“ u postupanju nadležnih tijela, jer njihov propust djelovati ekspeditivno tada ima puno veću težinu. ${ }^{56}$ Stoga je opravdano upozoriti na posljedicu potrošačke insolventnosti: smanjenje društvenih kontakata, socijalno isključenje insolventnih potrošača, dok pritom nerijetko potrošač živi na granici siromaštva. U praksi je, međutim, odnos između ispunjenja plana otplate duga i otpusta dugova višestruko složeniji. Naime, duljina trajanja postupka izravno utječe i na troškove, a kako dužnici često osjećaju teške posljedice i prije negoli je postupak započeo, postoji stvaran rizik da će se dužnik s ograničenim sredstvima tijekom razdoblja kušnje teško nositi, posebno u vrijeme obiteljskih tragedija, nepredviđenih troškova i da će tako ponovno pasti u druge troškove. Također, dulje razdoblje otplate duga može dovesti do izostanka ekonomske rehabilitacije dužnika, onemogućavajući mu dovršetak plana otplate duga. To nije korisno za dužnika, vjerovnika niti za društvo u cjelini. Nadalje, smanjen je i njegov pristup najosnovnijim uslugama te tržištu kapitala i tržištu rada čime postaje neupitna važnost predmeta spora za insolventnog potrošača.

\section{UMJESTO ZAKLJUČKA}

Stečajni zakon donesen je u svibnju $1996 .{ }^{57}$ i nakon toga mijenjan (dopunjavan) sedam puta. Donošenje Stečajnog zakona 1996., po uzoru na njemački Insolvencijski zakonik (Insolvenzordnung) ${ }^{58}$ i prestankom važenja Zakona o prisilnoj nagodbi, stečaju i likvidaciji, ${ }^{59}$ predstavljalo je korjenitu promjenu načina na koji se provodio stečajni postupak u Republici Hrvatskoj. Kod gotovo svih novela radilo se o namjeri prevladavanja ,akutnih“ problema u praksi i unapređenju sustava ostvarivanja stečajnopravne zaštite i to ubrzanjem stečajnog postupka. Ipak česte financijske krize uvjetovale su potrebu za radikalnom reformom stečajne regulative, a budući da tehnika provođenja stečaja nije dala pomake i da stečajni postupci traju u prosjeku preko 7 godina,${ }^{60}$ javila se potreba za implementiranjem novog zakona -

56 Grbić, S. op. cit., str. 75-77.

57 NN, br. 44/96.

58 Bundesgesetzblatt, 1994., I, str. 2866 s izmjenama.

59 NN, 53/91. i 54/94.

60 Za podatke vidi Šverko Grdić, Z.; Radolović, J. i Bagarić, L., „Solventnost poduzeća u Republici Hrvatskoj i u Europskoj uniji“, Ekonomski pregled, vol. 60, 2009., no. 5-6, str. 250. et seq.; Sajter, D., „Regionalna indiciranost stečajeva u Republici Hrvatskoj“, Ekonomski vjesnik, Ekonomski fakultet u Osijeku, br. 1 i 2, 2007., str. 31-42; Id., ,Procedura i praksa restrukturiranja u stečaju u Republici Hrvatskoj“", Zbornik Pravnog fakulteta u Splitu, vol. 47, 2010., no. 1, str. 742; Lesar, D., Hrvatski sabor, 
Dr. sc. Sanja Grbić i dr. sc. Dejan Bodul: O ustavnim i konvencijskim dvojbama uz Zakon o stečaju... Zbornik radova Pravnog fakulteta u Splitu, god. 53, 4/2016., str. 1011.-1038.

ZFPPN-a. Iako je donošenjem ZFPPN-a 2012. znatno izmijenjen stečajni postupak u Republici Hrvatskoj, u njegovoj dvogodišnjoj praktičnoj primjeni uočen je niz problema u tumačenju i učincima pojedinih odredbi i instituta, što će se pokušati otkloniti novim SZ-om. ${ }^{61}$ Dakle, iako indikativna metoda utvrđivanja činjenica ukazuje kako željeni ciljevi funkcionalizacije korporativne stečajnopravne zaštite još nisu ostvareni, pred zakonodavcem je novi/stari zadatak - provođenje postupka potrošačkog stečaja kroz rješenja ZSP-a. Naime, polazište za ZSP je također njemački Insolvenzordnung, koji je i sam radikalno izmijenio njemačko stečajno zakonodavstvo implementacijom instituta osobnog stečaja. ${ }^{62} \mathrm{~S}$ jedne strane, što doktrina, što postulati nomotehnike nalažu kako je orijentacija na već postojećem sistemu s iskustvom u praksi smislena, iz razloga što takva situacija omogućava korištenje strane sudske prakse i stručne literature kao pomoćnog sredstva u rješavanju problema koji se javljaju u primjeni zakona. Ipak, spuštajući se na praktičnu i empirijsku razinu njemačkog postupka potrošačkog stečaja, vidimo da je stopa uspješno okončanih postupaka tek neznatna (2-3\%) dok postupci u stvarnosti traju i do 11 godina $^{63}$ zbog čega se već dulje vrijeme razmišlja o reformi njemačkog postupka stečaja potrošača. ${ }^{64}$ Stoga, iako je „normativističkim optimizmom“ ZSP-a definirano kako će postupci, primjera radi, za najugroženije trajati i do 7 godina, pitanje je hoće li to razdoblje, što izvansudskog što sudskog postupka, u stvarnosti biti moguće poštovati ili će trajati još dulje. Iz prakse Europskog suda vidljivo je da će duljina trajanja tih postupaka vjerojatno dovesti do povrede prava

Klub zastupnika: Hrvatskih laburista - Stranke rada, Pregled podataka o stečajnim postupcima u toku pred Trgovačkim sudovima u Republici Hrvatskoj, Zagreb, od 6. travnja 2012., kao i podaci koji su dostupni na mrežnim stranicama Ministarstva pravosuđa: http://www.mprh.hr/Default.aspx (12. travnja 2016.).

${ }_{61}$ Primjerice, uvedeno je pravilo o trajanju postupaka u kojem je stranka stečajni dužnik te je istaknuto da je to uvijek hitan postupak koji se pred sudom prvog stupnja mora završiti u roku od 6 mjeseci od dana nastavka parničnih postupaka, a u žalbenom postupku u roku od šest mjeseci od dana primitka žalbe (čl. 166 SZ-a). Ipak treba biti svjestan da se radi o tzv. instruktivnim rokovima.

62 Detaljnije Braun, S., „German Insolvency Act: Special Provisions of Consumer Insolvency Proceedings and the Discharge of Residual Debts“, German Law Journal, vol. 7, 2005., no. 1, str. 59. et seq.

${ }^{63}$ Lechner, G., „The German Consumer Bankruptcy Process - (Not) A Rational Solution for All Filers for Bankruptcy“, u: Anderson, R.; Dubois, H.; Koark, A.; Lechner, G.; Ramsay, I.; Roethe, T.; Micklitz, H.-W. (eds.), Consumer Bankruptcy in Europe, Different Paths for Debtors and Creditors, European University Institute - Department of Law, Florence, 2011., str. 59-81.

${ }^{64}$ U ožujku 2006. Savezno ministarstvo pravosuđa proslijedilo je članovima radne skupine BundLänder prijedlog za raspravu pod naslovom „Nacrt Zakona o oslobađanju od dugova osoba bez ikakvih sredstava i o izmjenama insolvencijskog postupka za potrošače“ (njem. Entwurf eines Gesetzes zur Entschuldung völlig mittelloser Personen und zur Änderung des Verbraucherinsolvenzverfahrens). Dostupno na mrežnim stranicama: http://www.insorechtspfleger.de/inhalt/04_materialien/2006_03_03_ GE_ MRSB_VerbrIns.pdf (17. svibnja 2016.). Prijedlog je trebao biti temelj za raspravu unutar radne skupine i, unatoč svojem nazivu, on još ne predstavlja nacrt zakona Savezne vlade. Rezultati rasprave s Konferencije ministara pravosuđa predočeni su 2006., a na temelju zaključaka Savezno ministarstvo pravosuđa izradilo je Nacrt zakona. Tako Reform des Verbraucherinsolvenzrechts, Arbeitsgemeinschaft Insolvenzrecht und Sanierung im Deutschen Anwaltverein 2005. Dostupno na mrežnim stranicama: http:// www.arge-insolvenz recht.de/aktuelles (17. svibnja 2012.). 
na pošteno suđenje u razumnom roku prema čl. 6. Europske konvencije. Takvu povredu konvencijskog prava Republika Hrvatska mora ispraviti izmjenom odredbi ZSP-a koje definiraju duljinu razdoblja plana otplate duga. Štoviše, budući da je stečajni postupak prema praksi Europskog suda smatran sastavnim dijelom građanskog postupka, anegdotski dokazi ukazuju na to da duljina trajanja građanskih postupka pred nacionalnim sudovima u RH, i prije pokretanja i otvaranja stečajnog postupka, u većini slučajeva zna prekoračiti razuman rok. Analizirajući navedeno iz ekonomske perspektive, trebamo biti svjesni kako mnogi odnosi kao što je višegodišnje razdoblje otplate duga, u realnom društvenom životu podliježu drugačijim zakonitostima, prije svega ekonomskim. U konačnici, ekonomske kategorije ne poklapaju se s pravnim kategorijama, pa propisi koji to ne uvažavaju nužno dolaze u koliziju s realnim okolnostima i nemaju dodira sa stvarnošću što znači da su a priori određeni za neuspjeh. Možda je najbolje ustvrdio irski Vrhovni sud kada je raspravljao o trajanju irskog postupka potrošačkog stečaja ,... s obzirom na preduvjete za oslobađanje od preostalih obveza u stečaju, dužnik nema izgleda ishoditi otpust i ostat će u stečaju ostatak svog života, osim ako ne dobije na lutriji““. ${ }^{65}$

65 [2007.] IEHC 90. citirano prema Law Reform Commission, Personal Debt Management and Debt Enforcenent, LRC CP 56, 2009., str. 118. 


\section{Literatura:}

Bačić, A., „O sudskom aktivizmu ili o političkoj ulozi sudova“, Politička misao, vol. 35, 1998., no. 2, str. 106. et seq.

Barbić, J. (ur.), Hrvatsko insolvencijsko pravo, Hrvatska akademija znanosti i umjetnosti, Znanstveno vijeće za državnu upravu, pravosuđe i vladavinu prava, Zagreb, 2014., str. 1-227.

Bodul, D. et al., „Pitanja pravnog transplantiranja stečajnog zakonodavstva - kolizija pravne tradicije i ekonomskih čimbenika“, Zbornik Pravnog fakulteta Sveučilišta u Rijeci, vol. 35, 2014., no. 2, str. 555-595.

Bodul, D., „Odvjetnik kao pasivno legitimirana stranka u postupku stečaja potrošača rješenja i dvojbe“, Hrvatska pravna revija, 2016., br. 4, str. 48-58.

Bodul, D., „Osobni stečaj - globalni trend i hrvatska perspektiva“, Zbornik Pravnog Fakulteta Sveučilišta u Rijeci, vol. 32, 2011., br. 1. str. 351-377.

Bodul, D., Vuković, A., „Prilog raspravi o uvođenju potrošačkog stečaja: neka pitanja potrošačkog stečaja s međunarodnim/prekograničnim elementom“, Hrvatska pravna revija, 2013., br. 7-8, str. 61-67.

Braun, S., „German Insolvency Act: Special Provisions of Consumer Insolvency Proceedings and the Discharge of Residual Debts“, German Law Journal, vol. 7, 2005., no. 1, str. 59. et seq.

Čuveljak, J., „Oslobođenje od preostalih obveza u stečajnom postupku“, Pravo u gospodarstvu, vol. 48., 2008., br. 3, Zagreb, str. 955-970.

Dika, M., Insolvencijsko pravo, Pravni fakultet, Zagreb, 1998., str. 1-154.

Dutertre, G., van der Velde, J., Key extracts from a selection of judgements of the European Court of Human Rights and decisions and reports of the European Commission of Human Rights, Brusseles, Council of Europe, 1999., str. 84-85.

Feibelman, A., „Defining the Social Insurance Function of Consumer Bankruptcy“, American Bankruptcy Institute Law Review, vol. 13, 2005., str. 129-130.

Flint, R.E., „Bankruptcy Policy: Toward a Moral Justification for Financial Rehabilitation of the Consumer Debtor“, Washington and Lee Law Review, vol. 48, 2001., br. 1, str. 529.

Garašić, J., „Kako zakonski regulirati „osobni stečaj“ u Hrvatskoj“, Zbornik Pravnog fakulteta Sveučilišta u Zagrebu, vol. 61, 2011., no. 5, str. 1487-1514.

Grbić, S., Pošteno suđenje u građanskim postupcima u Hrvatskoj u svjetlu čl. 6., st. 1. Europske konvencije o ljudskim pravima, Pravni fakultet, Rijeka, 2014., str. 16-29. 
Halpern, S.W., „Application of the Doctrine of Commercial Impracticability: Searching for The Wisdom of Solomon“, University of Pennsylvania Law Review, vol. 135, 1987. br. 1, str. 1123. i 1159.

Harris, D. J., O’Boyle, M., Warbrick, C., Law of the European Convention on Human Rights, Oxford University Press, 2009., str. 376.

Jacoby, M. B., „Collecting Debts from the Ill and Injured: The Rhetorical Significance, But Practical Irrelevance, of Culpability and Ability to Pay", American University Law Review, vol. 51, 2001., br. 1, str. 250-266.

Kontrec, D., Ovrha na nekretnini, izlaganje sa skupa Hrvatska gospodarska komora Sektor za trgovinu, 23. forum poslovanja nekretninama. Materijali dostupni kod autora.

Law Reform Commission, Personal Debt Management and Debt Enforcenent, LRC CP 56, 2009., str. 118.

Lechner, G., „The German Consumer Bankruptcy Process - (Not) A Rational Solution for All Filers for Bankruptcy“, u: Anderson, R.; Dubois, H.; Koark, A.; Lechner, G.; Ramsay, I.; Roethe, T.; Micklitz, H.-W. (eds.), Consumer Bankruptcy in Europe, Different Paths for Debtors and Creditors, European University Institute - Department of Law, Florence, 2011., str. 59-81.

Legrand, P., „The Impossibility of Legal Transplants“, Maastricht Journal of European and Comparative Law, vol. 4, 1997., str. 111. et seq.

Lesar, D., Hrvatski sabor, Klub zastupnika: Hrvatskih laburista - Stranke rada, Pregled podataka o stečajnim postupcima u toku pred Trgovačkim sudovima u Republici Hrvatskoj, Zagreb, od 6. travnja 2012., kao i podaci koji su dostupni na mrežnim stranicama Ministarstva pravosuđa: http://www.mprh.hr/Default.aspx (12. travnja 2016.).

Lovrić, V., Stečaj nad imovinom dužnika pojedinca. Dostupno na mrežnim stranicama Visokog trgovačkog suda (17. siječnja 2016.).

Marković, N. i Kuzmić, M. (ur.), Reforma hrvatskog insolvencijskog prava - novi Stečajni zakon, Inženjerski biro, Zagreb, 2015., str. 1-267.

Mihelčić, G. u suradnji s Kontrec, D., Komentar Ovršnog zakona s opsežnom sudskom praksom i abecednim kazalom pojmova, Organizator, Zagreb, 2015., str. 350-500.

Omejec, J., „Konvencija za zaštitu ljudskih prava i temeljnih sloboda u praksi Europskog suda za ljudska prava“, Strasbourški acquis, Novi informator, Zagreb, 2013., str. 11161122 .

Radić, N., „Predstečajni postupak“, materijali sa savjetovanja Dani hrvatskog insolvencijskog i ovršnog prava, održanog u Zagrebu, 21. siječnja 2016., organizator pravni portal IUS INFO.

Radović, V., Individualni stečaj, Dosje, Beograd, 2006., str. 1-200. 
Reform des Verbraucherinsolvenzrechts, Arbeitsgemeinschaft Insolvenzrecht und Sanierung im Deutschen Anwaltverein 2005. Dostupno na mrežnim stranicama: http:// www.arge-insolvenz recht.de/aktuelles (17. svibnja 2012.).

Sajter, D., „,Procedura i praksa restrukturiranja u stečaju u Republici Hrvatskoj“, Zbornik Pravnog fakulteta u Splitu, vol. 47, 2010, no. 1, str. 742.

Sajter, D., „Regionalna indiciranost stečajeva u Republici Hrvatskoj“, Ekonomski vjesnik, Ekonomski fakultet u Osijeku, br. 1 i 2, 2007., str. 31-42.

Šverko Grdić, Z.; Radolović, J. i Bagarić, L., „Solventnost poduzeća u Republici Hrvatskoj i u Europskoj uniji““, Ekonomski pregled, vol. 60, 2009., no. 5-6, str. 250. et seq.

Turkalj, K., „Kako pravosuđe može dati doprinos gospodarskom rastu u Republici Hrvatskoj“, Pravo i porezi, 2016., br. 4, str. 59. et seq.

Uzelac, A., ,Kako organizirati efikasno izvršenje nespornih tražbina-neka komparativna iskustva“, Zbornik Konferencije Kako unaprijediti izvršni postupak u BiH, Sarajevo, 2009. Dostupno na mrežnim stranicama: ww.hjpc.ba/pr/msword /PR0AlanUzelac.doc (22. siječnja 2016.).

„Nacrt Zakona o oslobađanju od dugova osoba bez ikakvih sredstava i o izmjenama insolvencijskog postupka za potrošače“ (njem. Entwurf eines Gesetzes zur Entschuldung völlig mittelloser Personen und zur Änderung des Verbraucherinsolvenzverfahrens). Dostupno na mrežnim stranicama: http://www. insorechtspfleger.de/inhalt/04_ materialien/2006_03_03_GE_MRSB_VerbrIns.pdf (17. svibnja 2016.).

Europska Konvencija za zaštitu ljudskih prava i temeljnih sloboda, NN-MU, 18/97, 6/99, 14/02, 13/03, 9/05, 1/06 i 2/10.

Insolvenzordnung, Bundesgesetzblatt, 1994., I, str. 2866 s izmjenama.

Opća deklaracije o pravima čovjeka, NN-MU, 12/09.

Ovršni zakon, NN, 112/12., 25/13., 93/14.

Stečajni zakon, NN, 44/96. 29/99, 129/00, 123/03, 82/06, 116/10, 25/12., 133/12. i 45/13.

Stečajni zakon, NN, 71/15. od 01. rujna 2015.

Zakon o izvršnom postupku, NN, 53/91. i 91/92.

Zakon o obveznim odnosima, NN, 35/05., 41/08., 125/11., 78/15.

Zakon o parničnom postupku, NN, 53/91., 91/92., 112/99., 129/00., 88/01., 117/03., 88/05., 2/07., 96/08., 84/08., 123/08., 57/11., 25/13., 89/14.

Zakon o stečaju potrošača, NN, 100/15. od 18. rujna 2015.

Zakona o financijskom poslovanju i predstečajnoj nagodbi (NN, 108/12., 144/12., 81/13. i 112/13. (71/15. i 78/15.). 
Zakon o prisilnoj nagodbi, stečaju i likvidaciji, NN, 53/91. i 54/94.

Zakon o vlasništvu i drugim stvarnim pravima, NN, 91/96., 68/98., 137/99., 22/00., 73/00., 114/01., 79/06., 141/06., 146/08., 38/09., 153/09., 90/10., 143/12., 152/14.

Back protiv Finland, presuda, 20. srpnja 2004., zahtjev br. 37598/97.

Bassani protiv Italije, presuda, 11. prosinca 2003., br. 47778/99.

Capital Bank AD protiv Bugarske, presuda, 24. studenoga 2005., br. 49429/99.

Ceteroni protiv Italije, presuda, 15. studenoga 1996., Reports of Judgments and Decisions 1996-V.

Erkner i Hofauer protiv Austrije, presuda, 23. travnja 1987., Serija A, br. 117.

Feldbrugge protiv Nizozemske, presuda, 29. svibnja 1986., Serija A, br. 99.

Guincho protiv Portugala, presuda, 10. srpnja 1984., br. 8990/80.

Interfina and Christian della Faille d'Huysse protiv Belgije, odluka, 4. svibnja 1987. br. 11101/84.

Ismeta Bačić protiv Hrvatske, presuda, 19. lipnja 2008., br. 43595/06.

König protiv Savezne Republike Njemačke, presuda, 28. lipnja 1978., Serija A, br. 27.

Ringeisen protiv Austrije, presuda, 16. srpnja 1971., Serija A, br. 13.

Roche protiv Ujedinjenog Kraljevstva, presuda, 19. listopada 2005., br. 32555/96.

S.p.r.1. ANCA and Others protiv Belgije, odluka, 10. prosinca 1984., Decisions and Reports 40.

Scopelliti protiv Italije, presuda, 23. studenoga 1993., Serija A, br. 278.

Stran Greek Refineries i Stratis Andreadis protiv Grčke, presuda, 9. prosinca 1994., Serija A, br. 301-B.

Sukobljević protiv Hrvatske, presuda, 2. studenoga 2006., br. 5129/03.

Zimmermann i Steiner protiv Švicarske, presuda, 13. srpnja 1983., Serija A, br. 66. 


\section{ON CONSTITUTIONAL AND CONVENTIONAL DOUBTS WITH THE CONSUMER BANKRUPTCY ACT- DOES THE SEVERAL YEAR PLAN TO PAY OFF DEBTS IN THE CONSUMER BANKRUPTCY ACT REPRESENT A VIOLATION OF THE RIGHT TO TRIAL WITHIN A REASONABLE TIME?}

The precedential character of the European Convention law for the protection of human rights and fundamental freedoms (further in the text referred to as: European Convention or ECHR), which through the practice of the European Court of Human Rights (further: European Court or ECtHR) develops like a ,living "instrument, leading to every concept of art. 6 requiring an explanation of a hundred pages. In this context ECtHR in its judgements has analysed the so called. „tacit rights“ which are not directly mentioned in the text of the Convention, but are created through the judicature for, exempli causa, bankruptcy (corporative and consumer) procedure. On the other hand, the fact is that bankruptcy represents extra-court adjudication procedure, in extremis, in which time is one of the most significant elements. Time lessens the value of property and the more time passes in a bankruptcy procedure creditors when procedures are concluded will have access to less money while at the same time debtors- consumers will be deprived because they will have less chance for economic-social „rehabilitation“. This paper, analyses two complementary topics which we have, through argumentation, linked to a single whole. That is, in the given context, the authors examine whether the several year duration of the consumer bankruptcy procedure (in some cases up to seven years) the defined Consumer Bankruptcy Act represents a violation of the right to trial within a reasonable time, that is, a violation of the right to resolve civil rights and duties of debtors and creditors within a reasonable time in art. 6 of ECHR and art. 29 of the Constitution of the Republic of Croatia. The complexity of the subject of investigation and set tasks condition the choice of method. So, the methodology used in the investigation includes the study of domestic and foreign literature, appropriate legal regulations as well as the analysis of court practice. In this paper, the practice of the European Court of Human Rights is particularly analysed in the procedures of art. 6 (right to a fair trial) and the Constitutional Court of the Republic of Croatia with art. 29, section 1 of the Constitution of the Republic of Croatia because we presume that knowledge of this could be key to understanding this problem area of work.

Key words: Consumer Bankruptcy Act, period of examining behaviour, standard of reasonable time 